\title{
Assessment of General effects and gastrointestinal prokinetic activity of Baccharis crispa in mice
}

\author{
Ana M. Velázquez, Zulma E. Mallorquín, Yenny Montalbetti, Miguel A. Campuzano-Bublitz, María C. Hellión-Ibarrola, \\ María L. Kennedy, Derlis A. Ibarrola* \\ Departamento de Farmacología, Facultad de Ciencias Químicas, Universidad Nacional de Asunción, Campus UNA, 2169. San Lorenzo, Paraguay.
}

\begin{tabular}{|c|c|}
\hline ARTICLE INFO & ABSTRACT \\
\hline Article history: & \multirow{5}{*}{$\begin{array}{l}\text { Baccharis crispa is commonly known to be used in the treatment of several digestive disorders and the primary } \\
\text { purpose of this study was to detect its acute toxicity. Its influence on general behavior, sleeping time and intestinal } \\
\text { transit activity in mice were followed as a mean of initial validation for popular use. The gastrointestinal effect } \\
\text { was determined by testing the influence of } B \text {. crispa }(\mathrm{Bc}) \text { on both intestinal motility (in vivo) and spontaneous } \\
\text { contractile response of isolated ileum (in vitro). Oral administration of } \mathrm{Bc} \text { showed low toxicity and induced a } \\
\text { significant shortening of sleeping time in mice. After in vitro evaluation on isolated ileum, doses of } 5.10^{-4} ; 10^{-4} \\
\text { and } 5.10^{-3} \mathrm{mg} / \mathrm{mL} \text { of Bc potentiated the contractile response to acetylcholine. The intestinal propulsive activity } \\
\text { increased with oral doses of } 1,5 \mathrm{and} 50 \mathrm{mg} / \mathrm{kg} \text { of Bc. After in vitro and in vivo gastrointestinal evaluations of } \\
\text { Bc extract, it was clear that an efficient prokinetic activity and a significant increase in spontaneous contraction } \\
\text { induced by acetylcholine in isolated mouse ileum occurred. These results partially support and justify the } \\
\text { traditional use of } B \text {. crispa to treat gastrointestinal disorders. }\end{array}$} \\
\hline Received on: June 04, 2018 & \\
\hline Accepted on: July 07, 2018 & \\
\hline Available online: March 05, 2019 & \\
\hline $\begin{array}{l}\text { Key words: Baccharis crispa, } \\
\text { mice, ileum, prokinetic activity, } \\
\text { sleeping time. }\end{array}$ & \\
\hline
\end{tabular}

\section{INTRODUCTION}

Traditional medicine has an important role in primary health care of the population worldwide [1]. Since ancient times, medicinal plants have been used by man as therapeutic agents against many diseases, including those affecting the digestive system. Functional dyspepsia is one of the most common digestive disorders in western countries [2]. Despite the frequency of this disorder, a completely effective drug treatment is not yet available. Phytotherapy provides an effective and safe alternative approach that can improve the most common symptoms and in many cases, their use apparently had no significant side effects. Convincing data supporting the use of any herbal therapies are lacking [3].

The genus Baccharis is one of the most important in the Asteraceae family and it is a native shrub from the south of Brazil, Paraguay, Uruguay and Argentina [4,5]. In Paraguay, Baccharis trimera, $B$. microcephala and B. crispa, are commercialized under the local name jaguarete ka'a. The Infusion, decoction or tincture of aerial parts are

\section{${ }^{*}$ Corresponding Author}

Derlis A. Ibarrola, Departamento de Farmacología, Facultad de Ciencias Quimicas, Universidad Nacional de Asunción, Campus UNA, 2169. San Lorenzo, Paraguay.E-mail:dibarrol@qui.una.py used in folk medicine to treat anemia, cholelithiasis and gastrointestinal, bladder, liver, and kidney diseases $[6,7,8]$. In the region, $\mathrm{Bc}$ has been highly demanded its medicinal properties and for the preparation of tonic beverages. It is popularly used as an antiseptic, antirheumatic, cholagogue, diuretic and for liver disease [9]. Furthermore, the aerial part is used for wound healing and treatment of skin diseases and ulcers due to its antimicrobial activity [10] and to its diuretic and purifying effects. It is also claimed as useful for the treatment of gout, venereal sores and for leprosy. External use as gargling infusion has been indicated in angina and pharyngitis [6].

Aqueous extracts of the aerial parts of B. trimera, B. crispa and B. usterii (Asteraceae) showed significant free radical scavenging activity [11]. Protection against experimental ulcers due to indomethacin, alcohol, stress, and inhibition of gastrointestinal secretions has been reported for $B$. trimera [5]. Furthermore, antimicrobial activity against Bacillus subtilis, Micrococcus luteus and to a lesser extent against Staphilococcus aureus has been attributed to genkwanin and apigenin, isolated in aqueous, hydro-alcoholic and alcoholic extracts of $B$. nitida $[4,10]$. In this study, hydro-ethanolic extract of B. crispa was tested in order to determine its safety (acute toxicity and general activity) and the effect on the behavioral profile, sleeping time, and gastrointestinal activity (in vivo intestinal transit and in vitro effect on spontaneous contraction of isolated ileum) in mice. 


\section{MATERIALS AND METHODS}

\subsection{Plant Material and Extraction}

Aerial parts of Baccharis crispa Spreng were collected in 2011 in Villeta, Paraguay. A voucher specimen was filed with the herbarium of Facultad de Ciencias Químicas, Universidad Nacional de Asunción (CC \& AV 1322). Fresh samples were dried in an oven at $38^{\circ} \mathrm{C}$ for 4 days and then ground, and the powder was extracted with a mixture of ethanol: water (70:30) by a conventional reflux method for $1 \mathrm{~h}$, then filtered and evaporated under reduced pressure. The material obtained was subsequently frozen and lyophilized. The hydro-ethanolic extract of B. crispa $(\mathrm{Bc})$ was stored at room temperature in a desiccator until use. The extract was suspended in $2.5 \%$ ethanol in distilled water until a smooth homogenous suspension was formed and used for biological assays.

\subsection{Preliminary Phytochemical Analysis}

Phytochemical analysis was performed according to the methodology described $[12,13]$, based on the color typically developed by major chemical groups.

\subsection{Experimental Animals}

Swiss albino male and female mice, weighing 20-30 g were used. They were fed with balanced pellet diet and water ad libitum, housed in a plastic cage at a constant room temperature $\left(23-25^{\circ} \mathrm{C}\right)$, with 12:12 h light-dark cycle, in the humidity controlled environment (50$60 \%$ ). The animals were fasted for 12 hours prior to the experiment, allowing access only to water, and deprived of both, food and water, during the experiment. All experiments were conducted in accordance with international standards of animal welfare and the experimental protocol was approved by the Bioethical Committee of the Facultad de Ciencias Químicas (CEI 121/14). The minimum number of animals and duration of observation required to obtain consistent data were used, each animal was used once [14].

\subsection{Drugs}

Sodium chloride, potassium chloride, calcium chloride and magnesium chloride were obtained from Wako Pure Medical Industries Ltd (Japan). Sodium bicarbonate and D (+) anhydrous glucose from Merck (Darmstadt, Germany); sodium dihydrogen phosphate from Riedel -de Haen AG (Seelze, Germany). Sodium pentobarbital (Nembutal Abbott, Japan); Diazepam (Valium Roche Laboratory, Argentina); acetylcholine chloride from Sigma Chemical Company (St. Louis, MO, USA); atropine sulfate, neostigmine methylsulfate, ethanol and activated charcoal for pharmaceutical use were purchased locally.

\subsection{Acute Toxicity Study}

The acute toxicity study was done according to OECD 420 guidelines [15]. Female Swiss albino mice, weighing 20-30 g were dosed in a stepwise procedure using the fixed doses methods. Bc was administered orally in different doses $(5 ; 50 ; 300 ; 500$ and $2000 \mathrm{mg} / \mathrm{Kg})$, and $24 \mathrm{~h}$ observation was performed to identify the toxic effect, additionally, all animals were observed during 14 days searching for delay adverse events.

\subsection{General Behavior Effect}

Groups of five female mice were administered the extract $(5 ; 50 ; 300$ and $500 \mathrm{mg} / \mathrm{Kg}$ ) and observed in simultaneous comparison with a control group given vehicle $(0.1 \mathrm{~mL} / 10 \mathrm{~g}$ body weight $)$ at $0,5,15$, 30, 60 and 120 minutes after drug administration and also 24 and 48 hours later. Behavioral, physiological and neurological alterations and neurotoxicity symptoms were recorded according to a standardized observation grid [16].

\subsection{Pentobarbital-Induced Hypnosis}

Male mice were distributed into six groups of eight animals and one hour after oral administration of water $(0.1 \mathrm{~mL} / 10 \mathrm{~g}$ body weight); 5,50 or $500 \mathrm{mg} / \mathrm{kg}$ of Bc, or caffeine (used as stimulant, $30 \mathrm{mg} / \mathrm{Kg}$ ) each animal was injected with sodium pentobarbital (40 mg/kg, i.p.). Animals treated with diazepam $(0.5 \mathrm{mg} / \mathrm{kg}$ i.p. $)$, used as a positive central depressant agent in this assay received sodium pentobarbital, twenty minutes later. The latency to the loss of righting reflex (induction time in seconds) and the time required to recover righting reflex or awakening (sleeping time in minutes) were registered for each animal as previously described [17].

\subsection{Rota-Rod Test}

Mice were placed on a rotating rod $(2.5 \mathrm{~cm}$ diameter divided into six equal compartments, rotating at $12 \mathrm{rpm}$ ). Animals remaining on the rod for $2 \mathrm{~min}$ in two successive trials were selected for testing $24 \mathrm{~h}$ before the experiment. Groups of eight mice were treated with vehicle ( $0.1 \mathrm{~mL} / 10 \mathrm{~g}$ body weight p.o.); 5,50 and $500 \mathrm{mg} / \mathrm{kg}$ of Bc, p.o. or 0.5 $\mathrm{mg} / \mathrm{kg}$ diazepam, i.p. Sixty minutes after the $\mathrm{Bc}$ treatment, mice were placed on the spinning bar of the rota-rod apparatus for $1 \mathrm{~min}$. The time (s) spent on the rotating rod was recorded [18].

\subsection{Open Field Test}

Open-field activity was measured in a Plexiglas cage (height: $17 \mathrm{~cm}$, length: $30 \mathrm{~cm}$; width: $30 \mathrm{~cm}$ ) with black floor marked with white lines in $10 \mathrm{~cm}^{2}$ areas. Animals were randomly distributed into groups of eight animals. One hour after treatment with vehicle, Bc (5, 50 and 500 $\mathrm{mg} / / \mathrm{kg}$, p.o.) or diazepam $(0,5 \mathrm{mg} / \mathrm{kg}$, i.p. $)$, each mouse was placed in the centre of the arena and its ambulation (peripheral and central area), immobility time, rearing, grooming, and defecation were recorded for $5 \mathrm{~min}$ [18]. The number of grid lines crossed by both hind feet in a 5 min period was counted as an index of ambulation. After each trial, the open-field apparatus was wiped clean with ethanol (10\%) solution.

\subsection{Hole-Board Test}

The hole-board apparatus consisted of a Plexiglas cage (height: $15 \mathrm{~cm}$, length: $40 \mathrm{~cm}$; width: $40 \mathrm{~cm}$ ) with black floor marked with white lines limiting areas of $10 \mathrm{~cm}^{2}$. A total of 16 holes (diameter: $2 \mathrm{~cm}$ ) in an equidistant position was arranged in the arena. Group of eight animals randomly distributed were used per dose. One hour after administration of $\mathrm{Bc}(5,50$ and $500 \mathrm{mg} / \mathrm{kg}$, p.o.), water $(0.1 \mathrm{~mL} / 10 \mathrm{~g}$ body weight $)$ or diazepam $(0,5 \mathrm{mg} / \mathrm{kg}$, i.p.) each mouse was placed in the centre of the arena and its defecation, ambulation (peripheral and central area), rearing, grooming and head-dipping in the holes were recorded for 5 min. After each trial, the hole-board apparatus was wiped clean with ethanol (10\%) solution [18].

\subsection{In Vitro Contractile Response on Ileum}

After cleaning, longitudinal segments $(1.5 \mathrm{~cm})$ of mouse ileum were dissected out and placed in an organ bath $(10 \mathrm{~mL})$ containing Tyrode solution (concentration in $\mathrm{mM}$ : $\mathrm{NaCl} 135.0 ; \mathrm{KCl} 5.0 ; \mathrm{CaCl}_{2} 2.0 ; \mathrm{MgCl}_{2} 1.0$; $\mathrm{NaHCO}_{3} 15 ; \mathrm{NaH}_{2} \mathrm{PO}_{4}$ 1.0; Glucose 11 ; final $\mathrm{pH}$ of $7.4 \pm 0.2$.) maintained at $37 \pm 1^{\circ} \mathrm{C}$ and continuously bubbled with $\mathrm{O}_{2}$ and $5 \%$ of $\mathrm{CO}_{2}$. The tissue 
segments were mounted vertically. One end of the tissue was fastened to a glass tube support, and the other end was fixed to a horizontal balance writing lever at a tangent to a kymograph drum with an initial tension of $0.5 \mathrm{~g}$. The bathing solution was replaced with Tyrode solution at $10 \mathrm{~min}$ interval to avoid accumulation of metabolites. The preparations were allowed to equilibrate for 30 minutes before taking the control recordings. Thereafter, further calibration is performed for the tension using a $0.5 \mathrm{~g}$ calibration mass. After stabilization, the tissue segment was exposed to $10^{-7} \mathrm{M}$ acetylcholine (ACh) and $\mathrm{Bc}$, according to the protocol described in table 1, and the effect was recorded [19]. For each drug assay, five sets of experiments were done.

Table 1: Protocol of ACh and B. crispa $(\mathrm{Bc})$ extract administration to the ileum isolated from mouse.

\begin{tabular}{ccccc} 
& \multicolumn{2}{c}{ Effect of Bc in the contractile response } & \multicolumn{2}{c}{ Interaction of Bc + ACh } \\
Step & Drug & Concentration & Drug & Concentration \\
\hline 1 & $\mathrm{ACh}$ & $10^{-7}$ & $\mathrm{ACh}$ & $10^{-7}$ \\
2 & $\mathrm{Bc}$ & $10^{-4}$ & $\mathrm{Bc}+\mathrm{ACh}$ & $10^{-4}+10^{-7}$ \\
3 & $\mathrm{ACh}$ & $10^{-7}$ & $\mathrm{ACh}$ & $10^{-7}$ \\
4 & $\mathrm{Bc}$ & $5.10^{-4}$ & $\mathrm{Bc}+\mathrm{ACh}$ & $5.10^{-4}+10^{-7}$ \\
5 & $\mathrm{ACh}$ & $10^{-7}$ & $\mathrm{ACh}$ & $10^{-7}$ \\
6 & $\mathrm{Bc}$ & $10^{-3}$ & $\mathrm{Bc}+\mathrm{ACh}$ & $10^{-3}+10^{-7}$ \\
7 & $\mathrm{ACh}$ & $10^{-7}$ & $\mathrm{ACh}$ & $10^{-7}$ \\
8 & $\mathrm{Bc}$ & $5.10^{-3}$ & $\mathrm{Bc}+\mathrm{ACh}$ & $5.10^{-3}$ \\
9 & $\mathrm{ACh}$ & $10^{-7}$ & $\mathrm{ACh}$ & $10^{-7}$ \\
\hline
\end{tabular}

*Concentration of: $\mathrm{ACh}(\mathrm{mol} / \mathrm{L}) ; \mathrm{Bc}(\mathrm{mg} / \mathrm{mL})$

\subsection{Effect of Bc on Gastrointestinal Transit}

Groups of mice $(n=8)$ fasted 12 hours with free access to water were randomly allocated in six different groups. One group was treated orally with vehicle $(0.1 \mathrm{~mL} / 10 \mathrm{~g}$ body weight $)$ as a control. Another two groups were treated with neostigmine methylsulfate $(10 \mu \mathrm{g} / \mathrm{kg}$, s.c.) and atropine sulfate $(1 \mathrm{mg} / \mathrm{kg}$, i.p.) and considered as positive and negative controls, respectively. The remaining groups received oral doses of 5,50 and $500 \mathrm{mg} / \mathrm{kg}$ of Bc. One hour after treatments, 0.3 $\mathrm{mL}$ of charcoal suspension (10\%) was administered orally, according to individual timing, to all animals. After 30 minutes, the mice were sacrificed by cervical dislocation. The abdomen was instantly cut open, the small intestine was carefully removed and immediately straightened along a rule, and the location of the indicator was identified along the small intestine. The total intestinal length (from the pyloric sphincter to the ileocecal junction) and the length traveled by marker were measured and recorded $[19,20]$. The small intestinal transit was calculated as the percentage of the length traveled by marker substance related to the total length of intestine.

\subsection{Statistical Analysis}

Results are expressed as mean \pm S.D, and statistical analysis of the data was performed by Dunnet's Multiple Comparison test after one way ANOVA using GraphPad Prism 5.0 software (GraphPad Software, Inc. CA. USA). Differences were considered to be statistically significant when $p<0.05$.

\section{RESULTS AND DISCUSSION}

Preliminary phytochemical analysis of $B$. crispa revealed the presence of saponins, flavonoids, sugar, and glycosides. The acute toxicity was determined in female mice treated by intragastric cannulation with $B$ crispa (Bc) extract. After 24 hours, no mortality was evidenced, therefore $\mathrm{LD}_{50}$ is assumed to be greater than $2.000 \mathrm{mg} / \mathrm{kg}$. These results demonstrated that $\mathrm{Bc}$ extract does not show acute lethal toxicity. No difference in body weights after 14 days was detected. Behavior, postural reflex, grooming and responses to nociceptive stimuli kept normal, as well as water and food consumption compared to the control group.

\subsection{Effect of B. crispa on the Open-Field, Hole-Board, Rota- Rod Tests and Sleeping Time}

No differences in ambulatory (total, center and peripheral) and emotional (rearing, grooming, and defecation) behavior of mice were observed in the open-field test (data not being shown). Also, no effect on motor coordination in the rota-rod study (data not shown), or on exploratory behavior measured by the number of head dipping in hole board test $(p<0.05)$ were observed. These data show that $B c$ extract did not induce ambulatory or emotional changes in mice behavior neither in the hole-board nor the rota-rod test. Diazepam was used as anxiolytic positive control drug and no impairment in locomotion was observed at the dose used [21].

In the pentobarbital-induced sleeping time test in mice, the total sleeping time was significantly reduced by oral administration of 5, 50 and $500 \mathrm{mg} / \mathrm{kg}$ of $\mathrm{Bc}(p<0.001)$, independently of the dose (Figure $1)$. This suggests that the extract exerts a stimulating effect on central nervous system activity; similar to caffeine [17]. As expected, sleep times were increased significantly compared to the control group, when diazepam was administered $(p<0.01)$.

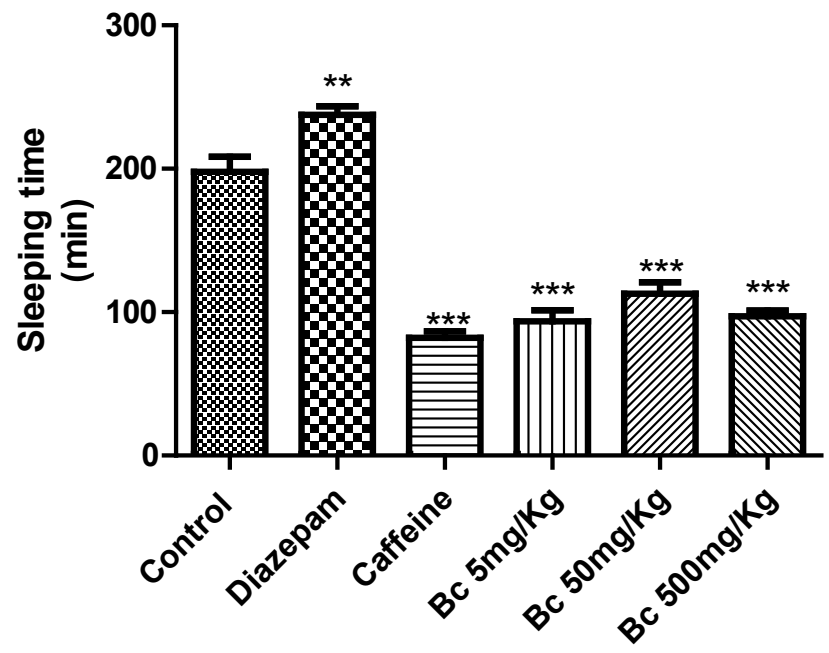

Figure 1: Effect of B. crispa extract (Bc) on hypnosis time induced by sodium pentobarbital in mice. Each bar represents the mean $\pm \operatorname{SEM}(n=5)$. One way ANOVA followed by Dunnett's multiple comparison tests were used. $* * p<$ $0.01 ; * * *<0.001$ was significantly different from control group.

\subsection{Effect of B. crispa on the Spontaneous Contractile Activity of Ileum Isolated from Mice}

The addition of $\mathrm{Bc}\left(10^{-4} ; 5.10^{-4} ; 10^{-3}\right.$ and $\left.5.10^{-3} \mathrm{mg} / \mathrm{mL}\right)$ did not modify the spontaneous contractile response of mouse isolated ileum. However, the recovery contractile response induced by $\mathrm{ACh} 10^{-7}$ $\mathrm{M}$, after washing with Tyrode solution, was significantly superior in comparison to control response obtained without extract application. As seen in Figure 2, after Bc pre-treatment, a statistically significant 
potentiation of the contractile response to the muscarinic agent was showed $\left(5.10^{-4} \mathrm{mg} / \mathrm{mL}, p<0.01 ; 10^{-4} \mathrm{mg} / \mathrm{mL}, p<0.05\right.$ and $5.10^{-3} \mathrm{mg} /$ $\mathrm{mL}, p<0.01$ ). Addition of ACh $10^{-7} \mathrm{M}$ was performed once the initial response was recovered after thorough rinsing of the tissue with the Tyrode's solution.

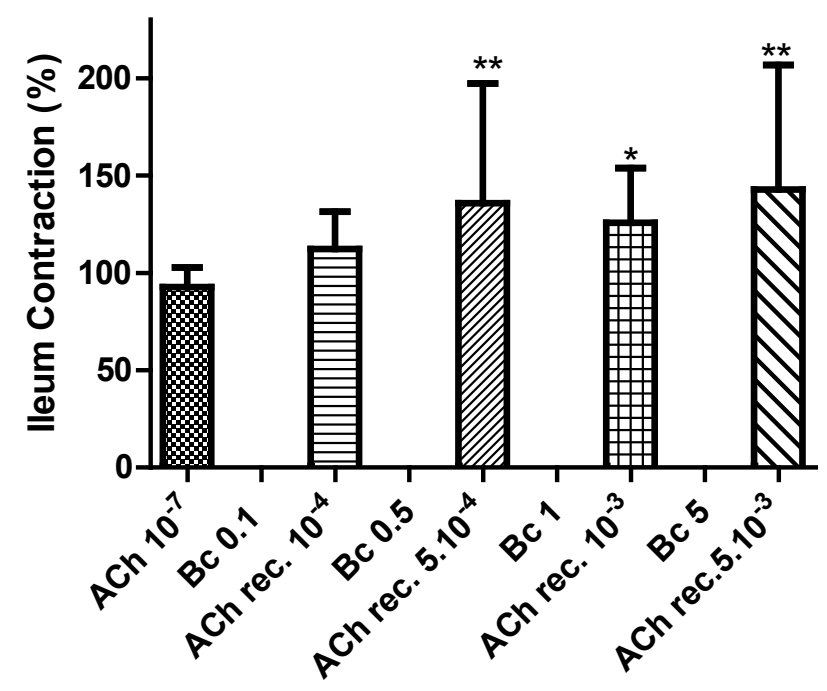

Figure 2: Effect of administration of B. crispa $(\mathrm{Bc}, \mathrm{mg} / \mathrm{mL})$ on the spontaneous contractile response, and recovery response (ACh rec.) induced by $\mathrm{ACh} 10^{-7} \mathrm{M}$ on mice ileum. Each bar represents the mean $\pm \mathrm{SD}$. $* p<0.05$;

$* * p<0.01$ are significantly different from contraction induced by control ACh $10^{-7} \mathrm{M}$.

Moreover, the contractile response in isolated ileum by adding $5.10^{-4}$; $10^{-3}$ and $5.10^{-3} \mathrm{mg} / \mathrm{mL}$ of Bc concomitantly with $\mathrm{ACh} 10^{-7} \mathrm{M}$, showed an increased contraction of this smooth muscle, and the recovery contractile response with ACh, after washing with Tyrode's solution, was also incremented (Figure 3).

\subsection{Effect of B. crispa on Gastrointestinal Motility in Mice}

A significant increase in intestinal charcoal migration was observed after oral administration of $1(p<0.01), 5(p<0.01)$ and $50(p<$ $0.05) \mathrm{mg} / \mathrm{kg}$ of Bc in mice, compared to control group (Figure 4). This result suggested a prokinetic activity of the extract. On the other hand, neostigmine (positive control, $10 \mu \mathrm{g} / \mathrm{kg}$, s.c.) induced an increased ( $p$ $<0.001$ ) and atropine (negative control, $1 \mathrm{mg} / \mathrm{kg}$, i.p.) a significant reduction in charcoal migration $(p<0.01)$ validating the method used.

Pharmacological evaluation of the hydro-ethanolic extract of $B$. crispa tested in mice exhibited an intestinal stimulation effect, both, in vitro and in vivo. The addition of $\mathrm{Bc}$ extract to isolated ileum did not modify the spontaneous contractile response. However, after washing, the recovery contractile response induced by $\mathrm{ACh} 10^{-7} \mathrm{M}$ was increased significantly in comparison to control obtained without the extract. Moreover, the contractile response of isolated ileum when the extract was concomitantly administered with ACh, showed an increased response compared to the one observed with ACh $10^{-7} \mathrm{M}$. Additionally, the recovery contractile response to $\mathrm{ACh} 10^{-7} \mathrm{M}$ after washing, was significantly increased.

The mechanism of how the pre-treatment with $\mathrm{Bc}$ extract enhances ACh induced contraction in this muscle remains unknown, it could be due to compounds in the raw material used for the assays that mimic muscarinic effects. Different mechanisms are involved in gastrointestinal smooth muscle contraction. Cholinergic nerves play a crucial role in the stimulatory regulation of smooth muscle activity and peristaltic movement. ACh acts on smooth muscle cells by binding to the muscarinic receptors on the cell surface, thus activating several intracellular signaling pathways, which leads to an increase in cytosolic calcium concentrations and, finally, smooth muscle contraction [22].

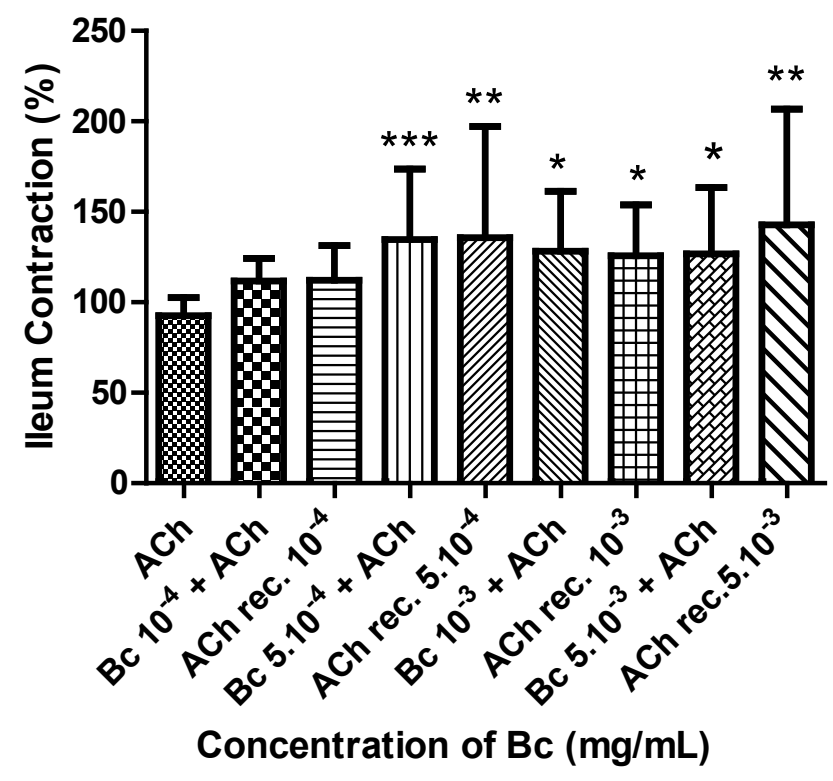

Figure 3: Influence of concomitant administration of B. crispa and $\mathrm{ACh} 10^{-7}$ $\mathrm{M}$ on ileum isolated from mice. Contractile response to $\mathrm{ACh} 10^{-7} \mathrm{M}$ (after washing with Tyrode's solution) of ileum treated with single dose of $10^{-4}$ (ACh

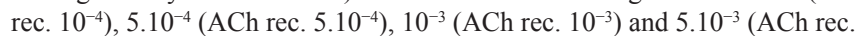
$\left.5.10^{-3}\right) \mathrm{mg} / \mathrm{mL}$ of Bc. Each bar represents the mean $\pm \mathrm{SD}$ of the percentage of contraction of the ileum. ${ }^{*} p<0.05 ; * * p<0.01 ; * * * p<0.001$ are significantly different from contraction induced by control ACh $10^{-7} \mathrm{M}$.

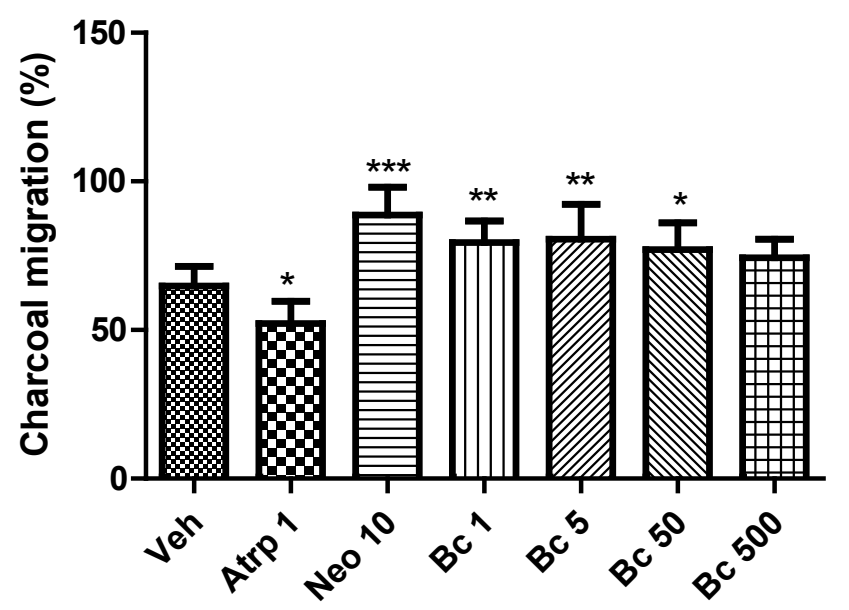

Figure 4: Effect of oral administration of vehicle (veh), atropine (Atrp, mg/ $\mathrm{mL})$, neostigmine $(\mathrm{Neo}, \mu \mathrm{g} / \mathrm{mL}), 1,5,50,500 \mathrm{mg} / \mathrm{kg}$ of $B$. crispa on intestinal transit of different groups of female mice $(n=8)$. Each bar represents the mean \pm SD percentage of charcoal migration in each group. ${ }^{*} p<0.05 ; * * p<0.01$; $* * * p<0.001$ significantly different from vehicle.

Groups of mice treated orally with $\mathrm{Bc}$ extract showed a significant increase in intestinal transit. The effect is dose-independent and it is seen nearly the same response with all doses, probably due to complex chemical compounds that could have different effects according to the amount present in each dose. The underlying mechanism of this 
effect is unknown and will require additional studies. The mechanism responsible for the increased propulsive activity might be originated by complex interactions of myogenic, neural and hormonal mechanisms. Each of these mechanisms might promote a higher availability of intracellular calcium, which leads to an increased intestinal prokinetic activity [22]. Intestinal transit speed is one of the factors determining the rate of absorption of luminal contents and regulates the bioavailability of foods and drugs administered orally. It is considered that the term digestive implies an increase of the secretions as well as in peristalsis of the gastrointestinal tract [19]. Both effects improve mixing, digestion, absorption, and propulsion of food. The results of this study confirmed a close association with the popular use of $B$. crispa as a digestive.

According to the literature, the main constituents of the Baccharis genus are phenolic and terpenoid compounds [23]. Preliminary phytochemical analysis of $B$. crispa revealed the presence of saponins, flavonoids, sugar, and glycosides. Recent evidence indicates that metabolites of phenolics may affect different intracellular signaling mechanisms that are crucial for cellular functions which may be related to some of the beneficial effects of natural products [24]. Whether this also applies to the active compounds of $B$. crispa remains to be clarified. Consequently, the effects observed, deserve further studies in order to elucidate the possible mechanisms of the contractile responses induced by Bc.

\section{CONCLUSION}

The findings indicated that Baccharis crispa has a low acute toxicity, no influence on behavioral performance, shortening of sleeping time and improvement of intestinal migration of charcoal marker in mice orally treated. Additionally, the present data indicate that Bc stimulates the in vitro ileum smooth muscle contraction in the mouse. This study, therefore, provides a scientific basis for the medicinal use of $B$. crispa as a digestive. More evidence is needed before using $\mathrm{Bc}$ as a potential therapeutic drug.

\section{CONFLICT OF INTEREST}

All authors have none to declare.

\section{REFERENCES}

1. World Health Organization, Estrategias de la OMS sobre medicina tradicional, Organización Mundial de la Salud, 2014.

2. Oshima T, Miwa H. Epidemiology of Functional Gastrointestinal Disorders in Japan and in the World. J Neurogastroenterol Motil 2015; 21:320-329.

3. Talley NJ. Functional dyspepsia: new insights into pathogenesis and therapy. Korean J Intern Med 2016; 31:444-456.

4. Rangel D, García I, Velasco J, Buitragro D, Velazco E. Actividad antimicrobiana de los extractos etanólico, acetónico y acuoso de Baccharis nítida (Ruiz et Pavon) Pers. Revista de Facultad de Farmacia 2001; 42:43-46.

5. Cruz Pádua B, Rossoni JV, Lopes de Brito Magalhães C, Martins Chaves M, Silva ME, Pedrosa ML, Bianco de Souza GH, Brandão GC, Vasconcelos Rodrigues I, Lima WG, Caldeira Costa D. Protective Effect of Baccharis trimera Extract on Acute Hepatic Injury in a Model of Inflammation Induced by Acetaminophen. Mediators of Inflammation 2014; 1-14, http://dx.doi.org/10.1155/2014/196598.

6. Cáceres MS, Machaín Singer AM. 2000. Manual de uso de hierbas medicinales del Paraguay. Uruguay: UNESCO.
7. Basualdo I, Soria N, Ortiz M, Degen R. Plantas medicinales comercializadas en los mercados de Asunción y Gran Asunción. Rojasiana 2004; 6:95-112.

8. Ibarrola D, Degen R. Eds. 2011. Catálogo ilustrado de 80 plantas medicinales del Paraguay. Asunción, Paraguay: AGR S.A.

9. Chaves AG, Torres LE, Massuh Y, Brunetti P, Ocaño SF, Castillo NE, Bustos JA, Ojeda MS. Phenotypic variability of four wild populations of Baccharis crispa Spreng mountains area of the Province of Córdoba, Argentina. Molecular Medicinal Chemistry 2010; 21:8-10.

10. Palacios P, Gutkind G, Rondina R, Torres R, Coussio J. Antimicrobial Activity of Baccharis crispa Sprengel ("Carqueja" FA) and Baccharis notosergila Gris. Acta Farm Bonaerense 1983; 1:5-10.

11. Simões-Pires CA, Queiroz EF, Henriques AT, Hostettmann K. Isolation and on-line identification of antioxidant compounds from three Baccharis species by HPLC-UVMS/MS with post-column derivatisation. Phytochem Anal 2005; 16:307-314.

12. Houghton P, Raman A. 1998. Laboratory Handbook for the Fractionation of Natural Extracts. London: Chapman \& Hall.

13. Wagner H, Bladt S. 1996. Plant drug analysis: a thin layer chromatography atlas. 2 ed. Berlin: Springer.

14. Real Decreto $17344,1201 / 2005$, Sobre protección de los animales utilizados para experimentación y otros fines científicos. Ministerio de la Presidencia-España, BOE 252, 34367-34391.

15. OECD. 2002. Test No. 420: Acute Oral Toxicity - Fixed Dose Procedure, OECD Guidelines for the Testing of Chemicals, Section 4. Paris: OECD Publishing 1-14.

16. Irwin S. Comprehensive observational assessment. A systematic quantitative procedure for assessing the behavioral and physiologic state of the mouse. Psychopharmacology 1968; 13:222-257.

17. Carlini EA. 1973. Farmacología prática sem aparelhagem. Sao Paulo: Ed. Sarvier.

18. De Lima TCM. 2002. Evaluación de la actividad y el comportamiento motor. In: Lapa AJ, Souccar C, Lima-Landman MTR, Monteiro de Lima TC, eds. Métodos de Evaluación de la Actividad Farmacológica de Plantas Medicinales. Florianópolis, Brasil: Editograf, CYTED/ CNPq 76-78.

19. Souccar C. 2002. Métodos farmacológicos utilizados para o estudo da atividade no trato gastrointestinal. In: Lapa AJ, Souccar C, LimaLandman MTR, Monteiro de Lima TC, eds., Métodos de Avaliação da Atividade Farmacológica de Plantas Medicinais. Florianópolis, Brasil: Editograf, CYTED/CNPq 28-53.

20. Williansom MS, Okpako DT, Evans FJ. 1996. Selection, Preparation and Pharmacological Evaluation of Plant Material. Vol 1. New York, USA, Wiley.

21. Fisher CE, Hughes RN. Effects of diazepam and cyclohexyladenosine on open-field behaviour in rats perinatally exposed to caffeine. Life Sciences 1996; 58:701-709.

22. Unno T, Matsuyama H, Izumi Y, Yamada M, Wess J, Komori S. Roles of M2 and M3 muscarinic receptors in cholinergic nerve-induced contractions in mouse ileum studied with receptor knockout mice. Br J Pharmacol 2006; 149:1022-1030.

23. Ramos Campos F, Bressan J, Godoy Jasinski V, Zuccolotto T, Silva LE, Bonancio Cerqueira L Baccharis (Asteraceae): Chemical Constituents and Biological Activities. Chem Biodiversity 2016; 13:1-17.

24. Crozier A, Jaganath IB, Clifford MN. Dietary phenolics: chemistry, bioavailability and effects on health. Natural Product Reports 2009, 26:1001-1043.

How to cite this article:

Velázquez AM, Mallorquín ZE, Montalbetti Y, Campuzano-Bublitz MA, Hellión-Ibarrola MC, Kennedy ML, Ibarrola DA. Assessment of General effects and gastrointestinal prokinetic activity of Baccharis crispa in mice. J App Biol Biotech. 2019;7(02):30-34. 